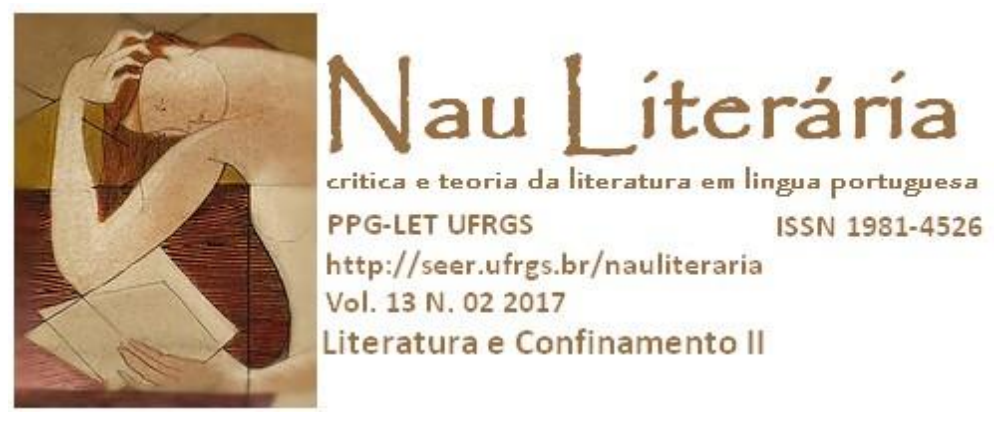

\title{
Exílio materno em tempos de repressão
}

Israel Augusto Moraes de Castro Fritsch ${ }^{1}$

O começo do sétimo livro do manauense Milton Hatoum mostra o cotidiano de um jovem brasileiro em Paris, em 1977 e 1978. Já nas primeiras linhas - em conversa sobre o Brasil com um aluno ao qual leciona português - a personagem se refere ao "terror político" do Regime Militar e deixa a sugestão de que se trata de uma obra sobre o exílio. Também será sobre o exílio, mas acaba-se descobrindo que a fuga do país ganhará expressão mais detalhada nos outros dois volumes da trilogia $A$ Noite da Espera, já anunciados, mas ainda a serem lançados. Nesta primeira parte, chamada $O$ Lugar Mais Sombrio (2017), o pano de fundo são os anos de chumbo, a partir de 1968 ano do Ato Institucional n. 5, do endurecimento do regime e da repressão. Dentro de certa tradição da literatura contemporânea brasileira sobre esse período da História, o livro focaliza o jovem Martim no coração do poder, Brasília, exilado, na verdade, do núcleo familiar, que desmorona com a separação dos pais.

Adolescente, Martim deixa a São Paulo familiar e o carinho dos avós para viver apenas com o pai na Capital Federal. Rodolfo torna-se engenheiro civil da Novacap, a estatal criada para construir a cidade, e procura, ali, reconstruir a vida em concordância com a ditadura. $\mathrm{O}$ filho, ao contrário, conquista amigos de esquerda - uma trupe teatral - e o trabalho em uma livraria onde confluem ideias libertárias, ponto de resistência e reuniões. O peso da repressão não vem apenas da vigilância policial, o próprio generalpresidente, o gaúcho Emílio Garrastazu Médici, assiste à apresentação de estreia do Prometeu Acorrentado da trupe - uma tragédia também parte de uma trilogia,

\footnotetext{
${ }^{1}$ Jornalista e mestrando em Literatura Comparada pela Universidade Federal do Rio Grande do Sul
} 
considerada, pelos integrantes do grupo teatral, a história de um rebelde que engana Zeus. Apesar de serem aplaudidos de pé pelo indesejado espectador, em uma mise-enscène política, eles não conseguem enganar a censura, e a estreia acaba sendo a única exibição do espetáculo.

À medida que a repressão aumenta, tentando escapar a todo o momento de ser detido pelos milicos, a busca do protagonista pela mãe ganha contornos de obsessão. Ela ficou para trás com o amante e é um contraponto ao Brasil cívico, da família, da tradição e da ordem que vigora e que vigia. A mãe é tão intangível quanto a Brasília nada porosa, cujos eixos e superquadras Martim percorre como qualquer adolescente e onde "tudo confunde, nada lembra lugar algum", enquanto tenta se conectar a ela, Brasília, e se reconectar ela, a mãe, sem muita informação sobre seu paradeiro. Essa procura pela mãe - "qual seria o destino de Lina? (...) Que caminhos iria percorrer, nessa vida errante que me excluía" - é tão ou mais angustiante que a resistência à repressão. Um dos momentos mais dramáticos é quando, depois de dois anos sem vê-la, Martim marca um encontro com a mãe em um hotel de Goiânia, meio do caminho entre onde ele está e ela se encontra, Minas Gerais. Mas ela não vem. Durante a espera, ele lê A Educação Sentimental de Gustave Flaubert. Também aqui, como no texto grego, a referência literária não é casual, pois a obra-prima francesa trata de um jovem que se desloca para a capital da França, mas tem seus objetivos de vida comprometidos por uma... revolução. A de 1848. Outro paralelo é terem ambos os livros, o flaubertiano e $O$ Lugar Mais Sombrio, protagonistas jovens e serem romances de formação. Em certo momento, enquanto espera a mãe, Martim se lembra de ter interrompido a leitura daquele romance durante um assassinato, "uma dupla traição, afetiva e política". Martim também era, ali, traído; politicamente, pelo pai, que se coloca ao lado do regime, e afetivamente, pela mãe distante, que não vem. Ele se questiona se a mãe teria lido $A$ Educação Sentimental, mas lembra ter visto na prateleira da infância apenas Madame Bovary, a história da mãe adúltera agora revisitada na narrativa de Hatoum.

Essa importância da mãe, mesmo fisicamente ausente da vida do rapaz, remete ao tamanho de outras mães na bibliografia do autor, desde Relato de um Certo Oriente (1989), cujo enredo é a busca por lembranças de uma família libanesa em Manaus, centralizada na matriarca Emilie, à Zana, a mãe dos gêmeos que geram uma crise familiar em Dois Irmãos (2000), também em Manaus. As crises se mantêm, mas agora 
Hatoum abandona o cenário semiurbano e úmido nortista pela secura da Capital Federal.

Fato também recorrente na literatura dele, que ganha ainda mais destaque em $O$ Lugar Mais Sombrio, é a narrativa fragmentada, calcada nas lembranças e nos relatos. Neste caso, em forma de diário esparso, ou "tempo salteado", a escrita é a junção de textos de cadernos, cadernetas, folhas soltas, cartas, diários e até guardanapos que são os fragmentos da memória, o que ficou de um tempo também despedaçado, de um adolescente prestes a ser exilado. "Talvez seja isto o exílio: uma longa insônia em que fantasmas reaparecem com a língua materna, adquirem vida na linguagem...”, escreve o narrador-protagonista, contundente. Que descaminhos percorreram filho e mãe? Como a memória, isso também é fragmentado na própria estrutura de trilogia a ser concluída. Por ora, ainda não sabemos. 